\title{
Barium and titanium enrichment of zoned phlogopite xenocrysts and phenocrysts in the Adamantin kimberlites, Québec, Canada.
}

\author{
R.L Barnett ${ }^{1}$ and C. Laroulandie ${ }^{2}$ \\ 1) R.L. Barnett Geoanalytical Ltd, London, ON, Canada, Bob Barnett, rbarnett@odyssey.on.ca \\ 2) Stornoway Diamond Corporation, North Vancouver, BC, Canada, claroulandie@stornowaydiamonds.com
}

\section{Introduction}

The Adamantin kimberlites are located in north central Québec, Canada, approximately $700 \mathrm{~km}$ north of Montreal, and $100 \mathrm{~km}$ south of the newly commissioned Renard Diamond Mine (Figure 1A). A till sampling program in 2015 highlighted the presence of kimberlite indicator minerals on the property. A reverse circulation (RC) drill program conducted in early 2016 resulted in the discovery of multiple kimberlite occurrences. These kimberlites are emplaced into Archean gneiss and granodiorite of the Epervanche Complex within the south-eastern portion of the Superior Craton (Dubé et al, 1976; Figure 1A). Petrological, petrographic and microprobe work indicates there are three mineralogically distinct groups of coherent kimberlites present, all containing compositionally-zoned phlogopite xenocrysts and phenocrysts (Figure 1B). Individual phlogopite crystals contain up to five distinct and successive compositional growth zones, with each grain containing a characteristic barium and titanium-rich zone near the margins of the grain. Results clearly indicate that significant chemical changes occurred in the chemical environment of the phlogopite crystals during formation and emplacement of the Adamantin kimberlites. Our data also provides strong evidence for the mobility of titanium, chrome and barium in fluids in the mantle, and mobility of titanium and barium during kimberlite ascent and emplacement.
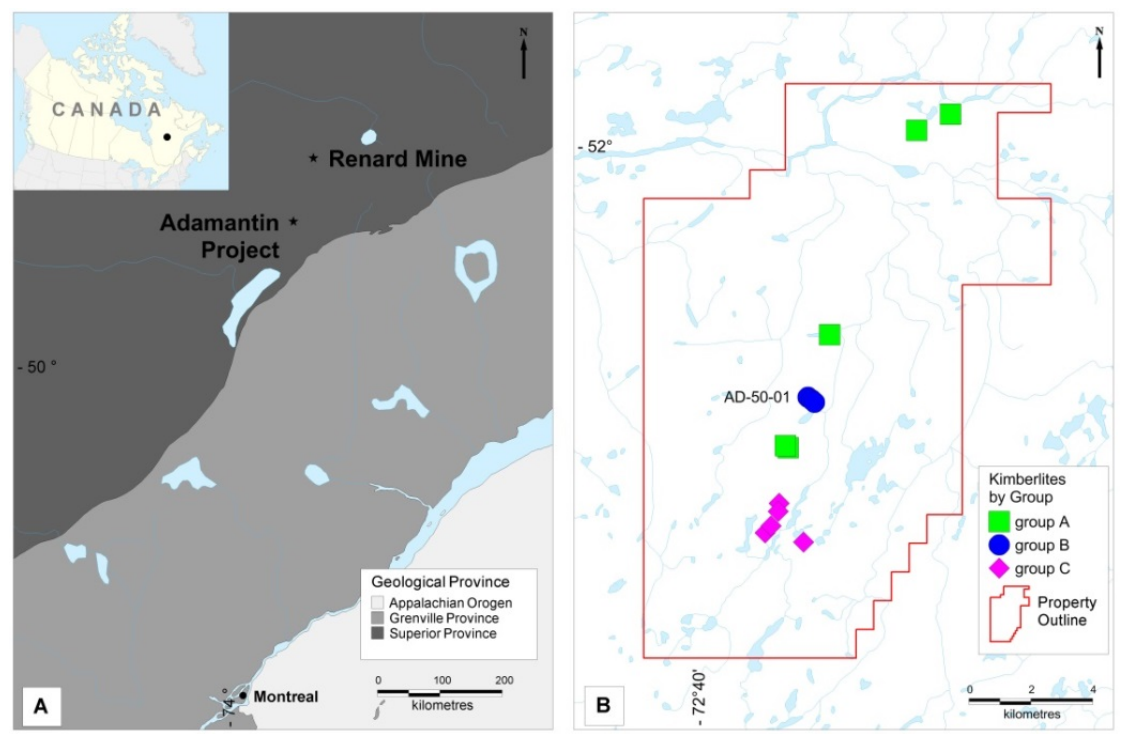

Figure 1: A) Location and regional geology of the Adamantin Project in relation to the Renard Diamond Mine B) Kimberlite occurrences separated into three mineralogically distinct groups as identified through petrological and microprobe work. Group A are perovskite-bearing carbonate phlogopite kimberlites; Group B are monticellite-bearing carbonate phlogopite kimberlites; and Group C are phlogopite carbonate kimberlites. Each group also contains different abundances of mantle-derived macrocrysts.

\section{Kimberlite Types}

Petrographic observation of kimberlite chips from the $\mathrm{RC}$ drilling reveals an average olivine macrocryst and phenocryst abundance of 30-50 modal \% set within a fine-grained crystalline 
groundmass of varying amounts of carbonate, serpentine, phlogopite, clinopyroxene, perovskite, spinel and apatite, with little to no country rock xenoliths. Phlogopite generally makes up 20-45 modal \% of the rock. These coherent kimberlites can be divided into three distinct mineralogical groups (Figure 1B). Group A is classified as a perovskite-bearing carbonate phlogopite kimberlite, where eclogite, pyrope and ilmenite are the main mantle-derived indicator minerals. Group B is classified as a monticellite-bearing carbonate phlogopite kimberlite, with chromite and chrome diopside, as well as lesser eclogite, pyrope and ilmenite. Finally, Group C is classified as a phlogopite carbonate kimberlite, with no mantle-derived indicator minerals other than olivine.

\section{Phlogopite Growth Zones}

Samples of kimberlite were examined petrographically and analyzed using a JEOL Model 733 Electron Microprobe at the laboratory facilities of R.L. Barnett Geoanalytical Ltd in London, Ontario, for the purpose of detailing mantle-derived indicator mineral compositions. Large mm-scale phlogopite crystals and clusters, commonly broken, all have core to margin compositional growth zones. Individual phlogopite crystals commonly display up to five successive, discrete compositional zones. Central core regions are magnesium-rich phlogopite with moderate titanium and little to no chrome, akin to mantle-derived phlogopites reported elsewhere (for example: Mitchell, 1986; see Zone 1 in Table 1 below) and can therefore be classified as phlogopite xenocrysts. A second zone with elevated titanium, chrome and with trace barium precedes a third and important growth zone that appears as a 'bright' ring in back scatter imaging, and is consistently enriched in barium, titanium and aluminum, but essentially without chrome (Table 1, Zone 3; Figure 2). A succeeding narrow outer growth zone is commonly magnesium-rich phlogopite with a low titanium and barium content. Smaller, zoned phlogopite crystals are also observed, sharing only the third characteristic 'bright ring', containing barium up to $6.50 \mathrm{wt} \% \mathrm{BaO}$, and the fourth magnesium-rich, low barium and titanium growth zones (Table 1; Figure 2A) and classified as phlogopite groundmass phenocrysts. The xenocrysts, and more commonly phenocrysts, are mantled by a fifth, low-aluminum, iron-rich, red tetraferriphlogopite rim. In poikilitic phenocrystic phlogopite crystals, the barium and titaniumenriched growth zone (Zone 3) commonly include minute grains of perovskite and zoned oxide atolls.

\begin{tabular}{|c|c|c|c|c|c|c|c|c|}
\hline Zone & Grain Type & Description & Al2O3 & TiO2 & Cr2O3 & $\mathrm{FeO}$ & MgO & $\mathrm{BaO}$ \\
\hline 1 & Xenocryst & Central core region of mantle-derived xenocrysts & 13.20 & 1.67 & 0.03 & 5.46 & 23.90 & 0.00 \\
\hline 2 & Xenocryst & Increasing titanium, chrome and barium & 15.56 & 4.54 & 1.24 & 4.83 & 21.22 & 0.38 \\
\hline 3 & Xenocryst and Phenocryst & Elevated barium and titanium, and low chrome & 19.41 & 2.53 & 0.04 & 5.04 & 21.82 & 3.31 \\
\hline 4 & Xenocryst and Phenocryst & Magnesium-rich, with a low titanium and barium content & 15.85 & 1.95 & 0.02 & 6.32 & 23.22 & 0.39 \\
\hline 5 & Xenocryst and Phenocryst & Tetraferriphlogopite rim & 1.08 & 0.17 & 0.00 & 18.21 & 24.75 & 0.08 \\
\hline
\end{tabular}

Table 1: Typical chemistry of the five successive phlogopite growth zones for both xenocrysts and phenocrysts from drill hole AD-51-01 (Figure 1B and Figure 2A). Oxide analyses in $w t \%$.

\section{Discussion}

Phlogopite in kimberlite is generally characterized by high chrome, high magnesium and elevated titanium contents (Mitchell, 1995). An interesting and important feature of the characteristic titanium and barium rings observed in both the xenocrysts and phenocrysts at Adamantin, is that they also plot within the 'kimberlite groundmass micas' region on Al-Ti and Al-Fe plots (Mitchell, 1995). These overall chemical evolution trends do not show, however, the important and significant variations in chrome and barium. In Figure 3 we present an Al-Ti plot which demonstrates this relationship. The compositional correlation of elevated barium and aluminum is indicative of a coupled substitution in phlogopite, which also includes titanium.

Experimental studies indicate that the substitution of titanium into the phlogopite structure increases with temperature at any pressure (Tronnes et al, 1985). We propose that in the upper-lower mantle transition, under conditions of high temperature and pressure, titanium is preferentially incorporated into phlogopite over barium regardless of the overall barium content, and hence the barium content of the primitive xenocryst cores are characteristically low. It is suggested that only upon decompression 
in the earliest stages of kimberlite genesis, that barium is allowed, in significant amounts, into the phlogopite structure and accordingly forms the characteristic barian-titanian growth zone on 1) the xenocrysts, in a very short-lived, transitory and evolving chemical environment with decreasing temperature and pressure during ascent, and 2) the phenocryst crystals upon rapid cooling of the kimberlite melt. The interpretation of this relationship is that these groundmass phenocrysts nucleated in a scenario of rapid cooling, and that all available barium in the chemical environment immediately fractionated into the phlogopite structure in the near surface environment. The implication is that the characteristic barian-titanian growth zones on the xenocrysts also formed during ascent and in the near surface environment as did the phenocrysts. These phlogopites and the barium-titanium ring zone are important to understanding the overall genesis of the Adamantin kimberlites, and may prove to be useful to the understanding of other kimberlites, orangeites and related rocks as phlogopite is not only stable in the mantle but can also record changing geochemical conditions during emplacement.
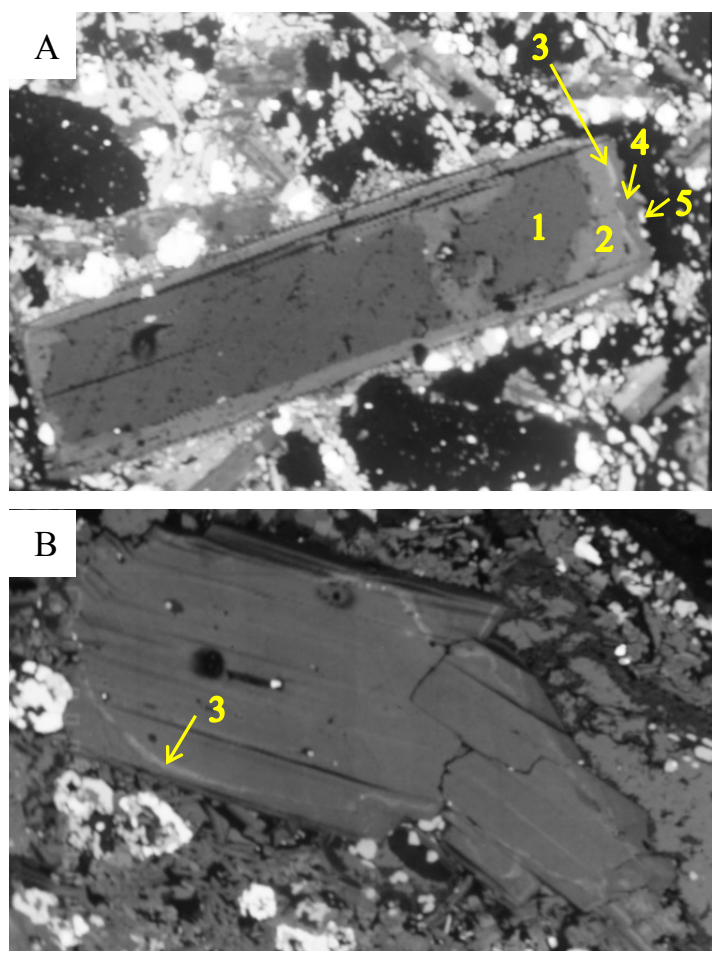

Figure 2: Back scatter images of A) a phlogopite phenocryst displaying the five growth zones listed in Table 1 by number, and B) a composite, multigranular phlogopite xenocryst, where the bright $\mathrm{Ba}-\mathrm{Ti}$ zone actually encloses both grains of the fragment in a continuous fashion $\left(2.52 \mathrm{wt} \% \mathrm{BaO}, 2.24 \mathrm{wt} \% \mathrm{TiO}_{2}\right)$.

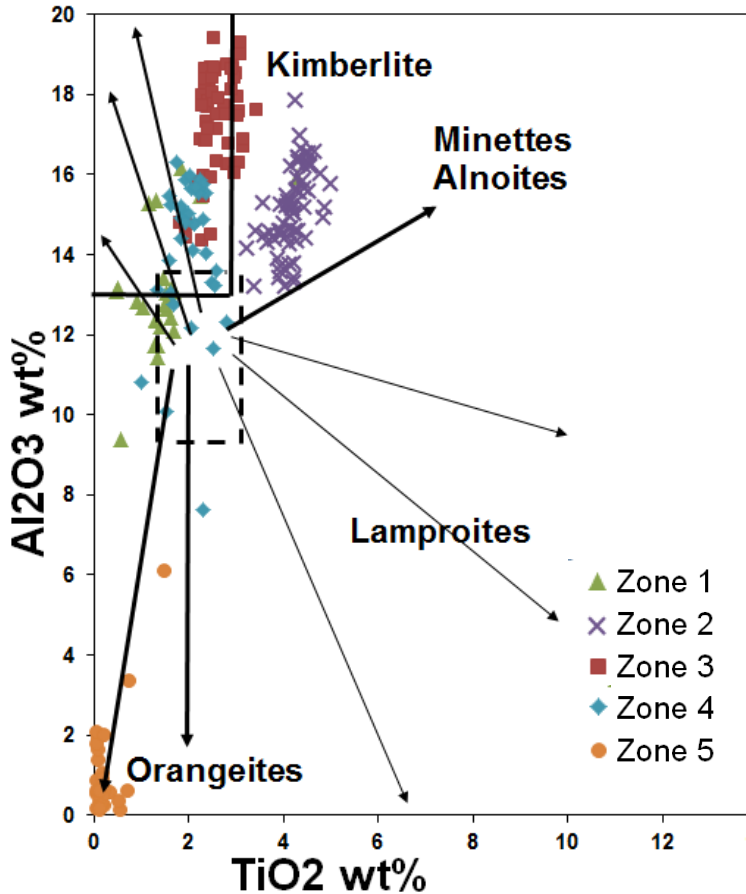

Figure 3: Chemistry of phlogopite crystals from kimberlite AD-51-01 (Figure 1B) classified by Zone \# (Table 1). Of note, the barium-titanium rich Zone 3 compositions clearly plot within the trend of kimberlite groundmass micas (after Mitchell, 1995).

\section{References}

Dubé C, Franconi A, Hocq M, Remick JH, Sharma KNM, Avramtchev L and Ducrot C (1976) Compilation géologique de territoire de la baie James. Ministère des Richesse Naturelles, Québec. Services de la documentation Technique, DP 358

Mitchell RH (1995) Kimberlites, orangeites, and related rocks, Plenum Press, New York 410 pp

Tronnes RG, Edgar AD, and Arima M (1985) A high pressure-high temperature study of $\mathrm{TiO} 2$ solubility in Mg-rich phlogopite: Implications to phlogopite chemistry. Geochimica et Cosmochimica Acta, 49, 2323-2329 